Sumerianz Journal of Business Management and Marketing, 2019, Vol. 2, No. 12, pp. 151-158

$\operatorname{ISSN}(e): 2617-0175, \operatorname{ISSN}(p): 2617-1724$

Website: https://www.sumerianz.com

(C) Sumerianz Publication

CC BY: Creative Commons Attribution License 4.0

\title{
Activate Climate of Change to Motivate Users toward Using Innovative Public E-Services
}

\author{
Prof. Yas A. Alsultanny \\ University of Baghdad, Iraq
}

\begin{abstract}
Purpose- The purpose of this paper is to assess the factors that motivate users toward using innovative public eservices that provided by e-governments, to enhance services and reduce costs. The effect of users' demographic characteristics on motivation factors are examined as well. Design/Methodology- A questionnaire survey was contact on sample of 676 users of public e-services, and research hypotheses were tested using variance analysis with SPSS software. Findings- The results showed that benefits, cost, risk, and opportunity have a positive significant relationship toward motivate users to use innovative public e-services. The demographic characteristics education, age, and job type have no statistically significant differences on using innovative public e-services, except gender have statistically significant effect on risk and opportunity. Originality/Value- paper extends the previous research that investigated impact of e-recruitment as one of the online services provided by organizations, innovative public e-services are important to any organization in doing services online with shortest time and less cost.

Keywords: E-government; Information technology; Benefits; Opportunity; Risk; Cost.
\end{abstract}

\section{Introduction}

Today, information technologies have influenced and changed our lives in different ways. Countries face great and multiple challenges, which create more, stress and produce many obstacles, when dealing with public and private services for organizations and governments. The organizations are required to change their methods of traditional management and adopt modern concepts if they want to achieve their goals efficiently and effectively in order to reach development and distinction (Waaer, 2010).

Government organizations around the world are increasingly making their services available online. Egovernment services are very important in reducing costs and improving services compared to traditional modes of government services delivery (Carter and Belanger, 2005). The provision of suitable public e-services is the factor affecting users' satisfaction and consequently, customer maintenance, and customer's satisfaction with provided services leads to recommending the products/services to others by the customers (Mansoori and Baradaran, 2010). Organizations in the public sector are under increasing pressure to demonstrate that their services are customerfocused, and that continuous performance improvement is being delivered (Ramseook-Munhurrun et al., 2010).

The public sector is facing large and fast changes that require a quick business process response, which can be secured by management applications and information integration by the governmental institutions, to guarantee the satisfaction of the customers and to itself sustain within the fields of competition, survival, and development. The benefit of public e-services is speed and convenience, while taking public approval or opinions, and thus helping to enhance government services (Dhindsa et al., 2013).

The purpose of this paper is to evaluate the factors that affect on motivating users to use innovative public eservices by examining the climate of change that the governmental organization can provide to users. Survey data collected from a sample of Arabic countries has been used e-services to examine users' motivation,

The paper consists of five sections. After the introduction, the research model is explained and research propositions are developed. Next, research methodology is presented, including sample description and research instrument. Data analysis and main research findings are provided in the fourth section. Finally, research results are discussed and directions for future researches are introduced.

\section{Theory and Research Hypotheses Development}

Electronic government refers to the delivery of government-related information and services online through the Internet (West, 2004). E-government initiatives have the potential to deliver better services (Yaghoubi et al., 2011). The United Nations defined e-government as "the use of Information and Communication Technology and its application by the government for the provision of information and public services to the people" (United Nations, 2012). The World Bank defined "e-government is the use of government agencies information technologies such as the Internet to have the ability to transform relations with citizens, businesses, and other arms of government" (World Bank, 2012). To maximize the benefits of e-government, service delivery and administration must be integrated across all branches of government, so called One-Stop-Shop e-government model (Alyaqoub, 2016).

There is still no agreed on definition about the concept of users' satisfaction because most of the definitions are about users' expectations or the comparison between users' expectations and their perceptions of service quality 


\section{Sumerianz Journal of Business Management and Marketing}

(Alangari, 2013). Many organizations are shifting from a product centric to a customer centric model to meet customer demands and satisfying those (Mazidi et al., 2014).

The results of Orgeron (2011) showed that different factors influenced users' satisfaction with the e-services provided by the Mississippi state USA government, the e-services quality needed to perform better to gain more users' satisfaction. Bavarsad and Mennatyan (2013), recommended that the public sector should encourage people to use e-government services. Prajakta and Hemalatha (2015), advised in their study to collect citizens' feedback frequently and advice mechanisms that will help the government provide e-services that are more effective.

Osman et al. (2011), introduced the COBRAS model with four factors; benefit, cost, risk, and opportunity that affect user's satisfaction. These factors influence the attitudes toward using e-services. The COBRAS model used to measure e-services success from diverse users' points of view. It depends on the benefit, cost, risk, and opportunity analysis of the users' engagement with e-services for determining the users' satisfaction with e-services (Mukumbareza, 2014). It also allows policy makers to compare one or more homogenous e-services in the same country or compare them to similar e-services in any other countries (AlBalushi and Ali, 2015). E-recruitment as one of the e-services increased users' satisfaction, because selecting candidates have high transparency (Alsultanny and Alotaibi, 2015).

\section{Research Methodology}

Based on COBRAS model (Osman et al., 2011) to test our expectation and gain better understanding for the factors affect on motivation users to use innovative public e-services, the research model of this paper was designed as shown in Figure 1. This model has four independent factors: benefit, cost, risk, and opportunity. These factors will be used to test innovative public e-services, which are considered independent variables. The demographic information added to COBRAS model to test the effect of demographic information: gender, education, age, and job type on motivation users to use innovative public e-services. Our propositions are;

H1: The e-government services factors (benefits, cost, risk, and opportunity) have a positive effect on motivate users to use innovative public e-services.

H2: There are statistically significant differences of the e-government services users' demographic information (gender, education, age, and job type) on the factors (benefits, cost, risk, opportunity.

H3: There are statistically significant differences of the e-government services users' demographic information (gender, education, age, and job type) on motivate users to use innovative public e-services.

The quantitative approach used in this paper. The research tool is a questionnaire developed from two parts, the first part is for demographic information and questions concerning general information. The second part consists of 33 statements divided into four factors and users motivation to use innovative public e-services. The statements of the questionnaire rated using the 5-points Likert-scales from 1 (strongly disagree) to 5 (strongly agree).

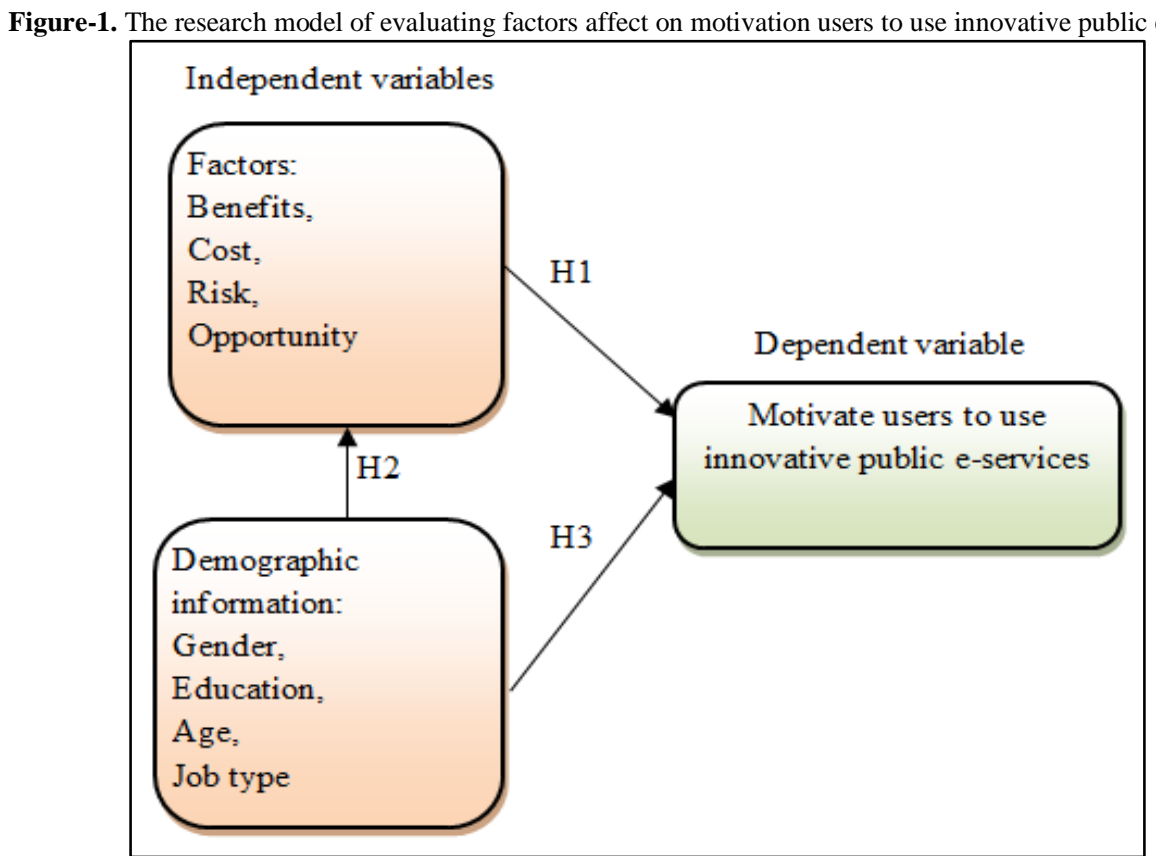

The relative acceptance was assigned based on the following formula:

Relative acceptance $=[\text { Mean/Top scale }(5)]^{* 100 \ldots(1)}$

The scale used to determine the respondents' acceptance level of the results are; 0-59\% Poor (P), 60-69\% Accepted (A), 70-79\% Good (G), 80-89\% Very Good (VG), and 90-100\% Excellent (E).

According to Gerstman (2003), the correlation has a different interpretation in the range of values, a value of $|r|>0.7$ which implies that there is a strong correlation between variables, $0.3<|r| \leq 0.7$ moderate correlation, and $0<|\mathbf{r}| \leq 0.3$ weak correlation.

Before distributing the questionnaire, the validity was checked. The content validity was investigated. Content validity was attained by selecting most of the statements of the questionnaire from literature and other previous 


\section{Sumerianz Journal of Business Management and Marketing}

research. The questionnaire piloted by interview with 8 university professors and experts in the field of information technology. They were asked to evaluate the content with regard to the language, accuracy, completeness, and clarity.

The questionnaire was sent randomly to 1045 real users of innovative public e-services in the Arabic region via an online questionnaire link. The data was gathered in three months; only 676 complete questionnaires were analyzed with an effective response rate of $64.7 \%$.

The data collected by questionnaire survey method were analyzed by using various statistical methods. Reliability is the degree to which the observed variable measures the true value and is error free (Zikmund et al., 2009). Cronbach's alpha $(\alpha)$ coefficient is used to test the reliability, the results of testing showed the Cronbach's alpha is .961 for all the factors, which indicates a high consistency between the statements of the questionnaire, because it is above then the suggested value of .70, as well as each factor has value above .70 (Field and Kim, 2008). Thus the measures used in this study valid and internally consistent.

The results of testing normal distribution by Kolmogorov-Smirnov showed the statements of the questionnaire have normal distribution, because the sig values for each statement are greater than 0.05 . The results of Levene's test for homogeneity showed that the collected data from responds are homogenous, because each statement has sig $>0.05$.

\section{Data Analysis and Research Findings}

The descriptive analysis of 676 responds was applied. The results of the analysis show that $457(67.6 \%)$ respondents in the sample are males and $219(32.4 \%)$ respondents are females. This means that most of the respondents are men. For education, $491(72.6 \%)$ respondents hold a university degree or higher, and $185(27.4 \%)$ of the respondents hold a high school degree or less. Most of the respondents $471(69.7 \%)$ are between 20-35 years, 103 $(15.2 \%)$ respondents in the sample are 20 years of age or less; respondents; $72(10.7 \%)$ respondents are 36-45 years; while the lowest $30(4.4 \%)$ respondents are above 45 years. For the job the majority of respondents $233(34.5 \%)$ are students, the public sector has a proportion of 197 (29.1\%) of the respondents and private sector has $137(20.3 \%)$, there are $53(7.8 \%)$ working in organizations that belong to the military sector, and the percentage of unemployed is $28(4.2 \%)$, there are $15(2.2 \%)$ retired respondents in the sample. Most of the respondents $556(82.2 \%)$ have an excellent ability to use computers, the others $120(17.8 \%)$ have a good ability to use computers.

Table 1 shows the average, standard deviation (SD), relative acceptance, level, and rank (importance of statement for each factor). The average value of the statements for the factor Benefits ranged between 3.52 and 4.13 , while the values of standard deviations ranged between 1.23 and 1.28. The relative acceptance range was between $73.0 \%$ and $82.6 \%$. The first rank goes to S4, which is stated: "The innovative public e-services are useful", with the highest average of 4.13, which is a very good level of acceptance. The average of this factor is 3.73 with relative acceptance of $74.7 \%$, which is a good level of acceptance. It can be considered that all the users agreed that this technology and its new features could helpful in completing their serves online. This result supported by Alrogibah (2011) study that the online information should be updated regularly to enhance the users' satisfaction.

The Cost factor has average values ranged between 3.01 and 4.28, while the values of standard deviations ranged between 1.26 and 1.43; the relative acceptance range is $60.2 \%$ to $85.6 \%$. The first rank goes to $\mathrm{S} 7$, which is stated: "Using the innovative public e-services saves my time", with the highest average of 4.28 , which is a very good level of acceptance. The average of this factor is 3.80 with relative acceptance of $76.0 \%$, which is a good level of acceptance. It can be considered that all the users agreed that this technology and its new features could save time and money. The results supported by the study held by Lehemets (2012), e-services will result in significant cost savings to governments and citizens alike.

The Risk factor has average values ranged between 2.64 and 3.85 , while the values of standard deviations ranged between 1.27 and 1.48 and the relative acceptance between $52.8 \%$ and $77.0 \%$. The first rank goes to S18, which is stated: "Information provided by users in the innovative public e-services is archived securely" with the highest average of 3.85 and standard deviation of 1.27 , and relative acceptance of $77 \%$, which is a good level. The average for this factor is 3.14 and relative acceptance of $62.8 \%$, which is an acceptable level. This result supported by Osman et al. (2011) study. The lower the e-service risk is the higher users' satisfaction.

For the Opportunity factor, the first rank goes to S23, which stated: "The innovative public e-services provide services at any time" with the higher average of 4.03 and standard deviation 1.30, which is very good level. The average for this factor is 3.67 with a standard deviation 1.31, and relative acceptance $73.6 \%$, which is good level of acceptance. This result is supported by Lehemets (2012) that e-service support includes accessing the services at any time and from any place, personalization of e-services, several delivery periods, responsiveness, process, more attractive, and error correction during a transaction.

The motivate users to use innovative public e-services factor has the average value of the statements ranged between 3.71-4.02, while the values of standard deviations ranged between 1.22-1.31. The first rank goes to S32, which states: "I advise my friends to use the innovative public e-services continuously", with highest average 4.02 and standard deviation 1.31, which is a very good acceptance level. The average of this factor is 3.86 with a standard deviation 1.26, and relative acceptance $77.2 \%$, which is a good acceptance level. It can be concluded that users are generally satisfied with the innovative public e-services therefore; they are willing to use it in the future and leave the traditional methods. 
Table-1. Descriptive statistics of the study factors

\begin{tabular}{|c|c|c|c|c|c|c|}
\hline No & Statements & Average & SD* & $\begin{array}{l}\text { Relative } \\
\text { acceptance \% }\end{array}$ & Level & Rank \\
\hline S1 & $\begin{array}{l}\text { The instructions on performing innovative } \\
\text { public e-services are helpful }\end{array}$ & 3.67 & 1.26 & 73.4 & G & 3 \\
\hline S2 & $\begin{array}{l}\text { The referral links to the innovative public e- } \\
\text { services are useful }\end{array}$ & 3.78 & 1.26 & 75.6 & G & 2 \\
\hline S3 & $\begin{array}{l}\text { The information displayed on the innovative } \\
\text { public e-services website isupdated }\end{array}$ & 3.52 & 1.24 & 70.4 & $\mathrm{~A}$ & 6 \\
\hline S4 & The innovative public e-services are useful & 4.13 & 1.28 & 82.6 & V G & 1 \\
\hline S5 & $\begin{array}{l}\text { The innovative public e-services information } \\
\text { is well organized and useful }\end{array}$ & 3.65 & 1.24 & 73.0 & G & 5 \\
\hline S6 & $\begin{array}{l}\text { The drop-down menus are useful for } \\
\text { completing the innovative public e-services }\end{array}$ & 3.66 & 1.23 & 73.2 & $\mathrm{G}$ & 4 \\
\hline \multicolumn{2}{|r|}{ Factor average - benefits } & 3.73 & 1.25 & 74.7 & \multicolumn{2}{|l|}{ Good } \\
\hline S7 & $\begin{array}{l}\text { Using the innovative public e-services saves } \\
\text { my time. }\end{array}$ & 4.28 & 1.29 & 85.6 & VG & 1 \\
\hline S8 & $\begin{array}{l}\text { The innovative public e-services steps take } \\
\text { several attempts to complete the service due } \\
\text { to system breakdowns }\end{array}$ & 3.01 & 1.35 & 60.2 & A & 7 \\
\hline S9 & $\begin{array}{l}\text { It takes a short period of time to } \\
\text { acknowledge the completion one } \\
\text { innovative public e-services } \\
\text { in }\end{array}$ & 3.64 & 1.26 & 72.8 & $\mathrm{G}$ & 6 \\
\hline S10 & $\begin{array}{l}\text { Using the innovative public e-services saves } \\
\text { my money }\end{array}$ & 3.75 & 1.40 & 75.0 & G & 5 \\
\hline S11 & $\begin{array}{l}\text { The innovative public e-services stops any } \\
\text { potential bribe to get the service }\end{array}$ & 4.10 & 1.40 & 82.0 & VG & 2 \\
\hline S12 & $\begin{array}{l}\text { The innovative public e-services reduces the } \\
\text { bureaucratic process }\end{array}$ & 3.88 & 1.34 & 77.6 & $\mathrm{G}$ & 4 \\
\hline S13 & $\begin{array}{l}\text { The innovative public e-services limit the } \\
\text { need for travel to get service }\end{array}$ & 3.94 & 1.43 & 78.8 & G & 3 \\
\hline \multicolumn{2}{|r|}{ Factor average - cost } & 3.80 & 1.35 & 76.0 & \multicolumn{2}{|l|}{ Good } \\
\hline S14 & $\begin{array}{l}\text { I am afraid that my personal information } \\
\text { may be used for other purposes }\end{array}$ & 2.95 & 1.48 & 59.0 & $\mathrm{P}$ & 3 \\
\hline S15 & $\begin{array}{l}\text { The innovative public e-services may lead to } \\
\text { the wrong payment action }\end{array}$ & 2.64 & 1.31 & 52.8 & $\mathrm{P}$ & 4 \\
\hline S16 & $\begin{array}{l}\text { I worry about conducting online transactions } \\
\text { because they require personal financial } \\
\text { information }\end{array}$ & 2.64 & 1.44 & 52.8 & $\mathrm{P}$ & 5 \\
\hline S17 & $\begin{array}{l}\text { Using the innovative public e-services leads } \\
\text { to fewer interactions with people }\end{array}$ & 3.63 & 1.38 & 72.6 & G & 2 \\
\hline S18 & $\begin{array}{l}\text { Information provided by users in the } \\
\text { innovative public e-service are archived } \\
\text { securely }\end{array}$ & 3.85 & 1.27 & 77.0 & $\mathrm{G}$ & 1 \\
\hline \multicolumn{2}{|r|}{ Factor average - risk } & 3.14 & 1.37 & 62.8 & \multicolumn{2}{|c|}{ Accept } \\
\hline S19 & $\begin{array}{l}\text { The innovative public e-service offers tools } \\
\text { for users with special needs (such as: touch } \\
\text { screen) }\end{array}$ & 3.44 & 1.32 & 68.8 & $\mathrm{~A}$ & 8 \\
\hline S20 & $\begin{array}{l}\text { The information is provided in multiple } \\
\text { languages }\end{array}$ & 3.27 & 1.23 & 65.4 & A & 10 \\
\hline S21 & $\begin{array}{l}\text { There is an encouraging incentive for using } \\
\text { the innovative public e-services }\end{array}$ & 3.43 & 1.39 & 68.6 & A & 9 \\
\hline S22 & $\begin{array}{l}\text { I can share my experience with others while } \\
\text { using innovative public e-services }\end{array}$ & 3.79 & 1.34 & 75.8 & $\mathrm{G}$ & 5 \\
\hline $\mathrm{S} 23$ & $\begin{array}{l}\text { The innovative public e-services provide } \\
\text { services at any time }\end{array}$ & 4.03 & 1.30 & 80.6 & VG & 1 \\
\hline S24 & $\begin{array}{l}\text { The innovative public e-services can be } \\
\text { reached from anywhere. }\end{array}$ & 3.97 & 1.37 & 79.4 & $\mathrm{G}$ & 2 \\
\hline $\mathrm{S} 25$ & $\begin{array}{l}\text { The information needed for using the } \\
\text { innovative public e-services are accessible }\end{array}$ & 3.88 & 1.30 & 77.6 & $\mathrm{G}$ & 3 \\
\hline S26 & $\begin{array}{l}\text { The innovative public e-services lead me to } \\
\text { the place of errors, if any, during a } \\
\text { transaction }\end{array}$ & 3.52 & 1.31 & 70.4 & $\mathrm{G}$ & 7 \\
\hline S27 & $\begin{array}{l}\text { The innovative public e-services allow me to } \\
\text { update my records online }\end{array}$ & 3.82 & 1.28 & 76.4 & $\mathrm{G}$ & 4 \\
\hline
\end{tabular}


Sumerianz Journal of Business Management and Marketing

\begin{tabular}{l|l|l|l|l|l|l}
\hline S28 & $\begin{array}{l}\text { The innovative public e-services can be } \\
\text { completed incrementally at different times }\end{array}$ & 3.64 & 1.31 & 72.8 & $\mathrm{G}$ & 6 \\
\hline Factor average- opportunity & 3.67 & 1.31 & 73.6 & \multicolumn{2}{l|}{ Good } \\
\hline S29 & $\begin{array}{l}\text { Generally, I am completely satisfied with the } \\
\text { innovative public e-services }\end{array}$ & 3.86 & 1.22 & 77.2 & $\mathrm{G}$ & 3 \\
\hline S30 & $\begin{array}{l}\text { I can use the services provided by the } \\
\text { innovative public e-services easily }\end{array}$ & 3.95 & 1.22 & 79.0 & $\mathrm{G}$ & 2 \\
\hline S31 & $\begin{array}{l}\text { I am satisfied with the speed of updating and } \\
\text { developing data and information on the } \\
\text { innovative public e-services }\end{array}$ & 3.78 & 1.27 & 75.6 & $\mathrm{G}$ & 4 \\
\hline S32 & $\begin{array}{l}\text { I advise my friends to use the innovative } \\
\text { public e-services continuously }\end{array}$ & 4.02 & 1.31 & 80.4 & $\mathrm{VG}$ & 1 \\
\hline S33 & $\begin{array}{l}\text { I am satisfied with the speed of innovative } \\
\text { public e-services information loading }\end{array}$ & 3.71 & 1.28 & 74.2 & $\mathrm{G}$ & 5 \\
\hline $\begin{array}{l}\text { Factor average - motivate users to use innovative } \\
\text { public e-services }\end{array}$ & 3.86 & 1.26 & 77.2 & $\mathrm{Good}$ \\
\hline
\end{tabular}

The Pearson's test was used to measure the correlation between the four factors (benefit cost, risk, and opportunity) and motivate users to use innovative public e-services. Table 2 presents the results of the testing. The Pearson's correlation coefficients have not revealed negative or very low correlations between factors examined. Furthermore, all of them were statistically significant at the level 0.01.7. In other words: there is a strong correlation between the benefits, cost, opportunity, and motivate users to use innovative public e-services with values 0.833 , 0.784 and 0.842 respectively, while the correlation between risk and motivate users to use innovative public eservices is weak with a value of 0.295 .

Table-2. The Pearson correlation

\begin{tabular}{l|l|l|l|l}
\hline No & Factor & Correlation Coefficients & Sig. \\
\hline 1 & Benefits & Motivate users to use & 0.833 & $0.000^{* *}$ \\
\cline { 5 - 5 } innovative public e- & 0.784 & $0.000^{* *}$ \\
\cline { 5 - 5 } 2 & Cost & services & 0.295 & $0.000^{* *}$ \\
\hline 3 & Risk & 0.842 & $0.000^{* *}$ \\
\hline 4 & Opportunity & & \multicolumn{2}{l}{}
\end{tabular}

The hypothesis H1 was tested by using simple linear regression. As shown in Table 3. The results showed that the factor of determination $r$ square $=.693$, between the motivate users to use innovative public e-services and benefit. This indicates a high effect of benefit on motivate users to use innovative public e-services, and there is a statistically significant effect of benefit on motivate users to use innovative public e-services. This results' are supported by a study held by Osman et al. (2011).

The factor of determination $\mathrm{r}$ square $=.615$ between the motivate users to use innovative public e-services and cost. This indicates a moderate effect of cost on motivate users to use innovative public e-services and there is a statistically significant effect of cost on motivate users to use innovative public e-services. These results assure that the cost is very important to increase the users' satisfaction. According to Al-Saraireh and Alnabhan (2014) the cost is important and has a relationship with user satisfaction.

The factor of determination $\mathrm{r}$ square= .087 between the motivate users to use innovative public e-services and risk, this indicates a weak effect of risk on motivate users to use innovative public e-services, and there is a statistically significant effect of risk on motivate users to use innovative public e-services. This result assures that the risk is important to improve the user satisfaction, which is supported by the study held by Alomar and Woods (2009) that the safety, trust, and security are considered as important factors that explain users' satisfaction of innovative public e-services.

The factor of determination $\mathrm{r}$ square $=.709$ between motivate users to use innovative public e-services and opportunity, there is astatistically significant effect of opportunity on motivate users to use innovative public eservices. This indicates that opportunity is very important to the users, which is supported by the study held by Osman et al. (2011).

Table-3. Simple linear regression for the hypothesis H1

\begin{tabular}{|c|c|c|c|c|c|c|c|}
\hline Factor & $\begin{array}{l}\text { Sum of } \\
\text { squares }\end{array}$ & $\begin{array}{l}\text { Mean } \\
\text { square }\end{array}$ & $\mathbf{r}$ & $\begin{array}{l}\mathbf{r} \\
\text { square }\end{array}$ & $\mathbf{F}$ & Sig. & Regression equation \\
\hline \multirow[t]{2}{*}{ Benefit } & 582.344 & 582.344 & .833 & .693 & 1520.490 & .000 & \multirow{2}{*}{$\begin{array}{l}\text { motivate users to use innovative public } \\
\text { e-services }=.540+.889 \text { (benefit) }\end{array}$} \\
\hline & 257.757 & .383 & & & & & \\
\hline \multirow[t]{2}{*}{ Cost } & 516.743 & 516.743 & .784 & .615 & 1075.492 & .000 & \multirow{2}{*}{$\begin{array}{l}\text { motivate users to use innovative public } \\
\text { e-services }=.502+.885 \text { (cost) }\end{array}$} \\
\hline & 323.357 & .480 & & & & & \\
\hline \multirow[t]{2}{*}{ Risk } & 73.086 & 73.086 & .295 & .087 & 64.127 & .000 & \multirow{2}{*}{$\begin{array}{l}\text { motivate users to use innovative public } \\
\text { e-services }=2.573+.411 \text { (risk) }\end{array}$} \\
\hline & 767.015 & 1.140 & & & & & \\
\hline \multirow{2}{*}{$\begin{array}{l}\text { Opport } \\
\text { unity }\end{array}$} & 73.086 & 73.086 & .295 & .087 & 64.127 & .000 & \multirow{2}{*}{$\begin{array}{l}\text { motivate users to use innovative public } \\
\text { e-services }=0.315+0.965 \text { (opportunity) }\end{array}$} \\
\hline & 767.015 & 1.140 & & & & & \\
\hline
\end{tabular}




\section{Sumerianz Journal of Business Management and Marketing}

Independent samples T-test and One-Way ANOVA used to test hypothesis H2. Table 4 shows that there are no statistically significant differences between males and females in benefit, and cost, However, risk and opportunity have statistically significant differences between female and male responses. The females have a higher demand for risk and opportunity than males, maybe because females need more opportunity to use the innovative public eservices anywhere for more privacy. On the other hand, they believe it is important to keep their information safe and secure. In addition, e-services are used more widely by males than by females. The study of Venkatesh and Davis (2000) recommended the importance of testing gender differences when analyzing technological use, including that of e-government web services.

The table also shows that education have no statistically significant differences in the study sample responses for all the factors, Maybe this is so because the innovative public e-services is suitable and easy for all users regardless of their educational level.

Table-4. Testing effect of gender and education benefit, cost, risk, and opportunity

\begin{tabular}{|c|c|c|c|c|c|c|c|c|}
\hline $\begin{array}{l}\text { Demographic } \\
\text { information }\end{array}$ & Factor & Type & $\begin{array}{l}\text { Num } \\
\text { ber }\end{array}$ & Means & SD & $\mathbf{T}$ value & df & Sig. \\
\hline \multirow[t]{8}{*}{ Gender } & \multirow[t]{2}{*}{ Benefit } & Male & 457 & 3.7338 & 1.084 & -.034 & \multirow[t]{2}{*}{674} & \multirow[t]{2}{*}{0.973} \\
\hline & & Female & 219 & 3.7367 & .963 & -.035 & & \\
\hline & \multirow[t]{2}{*}{ Cost } & Male & 457 & 3.7971 & 1.035 & -.109 & \multirow[t]{2}{*}{674} & \multirow[t]{2}{*}{0.913} \\
\hline & & Female & 219 & 3.8060 & .888 & -.115 & & \\
\hline & \multirow[t]{2}{*}{ Risk } & Male & 457 & 3.0670 & .820 & -3.647 & \multirow[t]{2}{*}{674} & \multirow[t]{2}{*}{0.000} \\
\hline & & Female & 219 & 3.3055 & .736 & -3.789 & & \\
\hline & \multirow{2}{*}{$\begin{array}{l}\text { Opport } \\
\text { unity }\end{array}$} & Male & 457 & 3.6256 & 1.002 & -2.036 & \multirow[t]{2}{*}{674} & \multirow[t]{2}{*}{0.042} \\
\hline & & Female & 219 & 3.7885 & .906 & -2.109 & & \\
\hline \multirow[t]{8}{*}{ Education } & \multirow[t]{2}{*}{ Benefit } & High school or less & 185 & 3.717 & .977 & -.268 & \multirow[t]{2}{*}{674} & \multirow[t]{2}{*}{0.789} \\
\hline & & University & 491 & 3.741 & 1.072 & -.280 & & \\
\hline & \multirow[t]{2}{*}{ Cost } & High school or less & 184 & 3.749 & .935 & -.816 & \multirow[t]{2}{*}{674} & \multirow[t]{2}{*}{0.415} \\
\hline & & University & 491 & 3.819 & 1.009 & -.845 & & \\
\hline & \multirow[t]{2}{*}{ Risk } & High school or less & 184 & 3.195 & .860 & 1.025 & \multirow[t]{2}{*}{674} & \multirow[t]{2}{*}{0.306} \\
\hline & & University & 491 & 3.124 & .778 & .979 & & \\
\hline & \multirow{2}{*}{$\begin{array}{l}\text { Opport } \\
\text { unity }\end{array}$} & High school or less & 184 & 3.672 & 1.001 & -.097 & \multirow[t]{2}{*}{674} & \multirow[t]{2}{*}{0.923} \\
\hline & & University & 491 & 3.680 & .965 & -.095 & & \\
\hline
\end{tabular}

One Way ANOVA used to test the effect of age and job type. Table 5 shows that the age and job type have no statistically significant effect on all the factors. Maybe this is so because the innovative public e-service is suitable and easy for all users regardless of their age categories and job type.

Table-5. Testing effect of age and job type on benefit, cost, risk, and opportunity

\begin{tabular}{|c|c|c|c|c|c|c|c|}
\hline $\begin{array}{l}\text { Demographic } \\
\text { information }\end{array}$ & Factor & $\begin{array}{l}\text { Sources of } \\
\text { variance }\end{array}$ & $\begin{array}{l}\text { Sum of } \\
\text { squares }\end{array}$ & df. & $\begin{array}{l}\text { Means } \\
\text { squares }\end{array}$ & $\mathbf{F}$ & Sig. \\
\hline \multirow[t]{12}{*}{ Age } & \multirow[t]{3}{*}{ Benefit } & $\begin{array}{l}\text { Between } \\
\text { Groups }\end{array}$ & .558 & 3 & .186 & \multirow[t]{3}{*}{.169} & \multirow[t]{3}{*}{.917} \\
\hline & & Within Groups & 738.645 & 672 & 1.099 & & \\
\hline & & Total & 739.203 & 675 & & & \\
\hline & \multirow[t]{3}{*}{ Cost } & $\begin{array}{l}\text { Between } \\
\text { Groups }\end{array}$ & 1.740 & 3 & .580 & \multirow[t]{3}{*}{.591} & \multirow[t]{3}{*}{.621} \\
\hline & & Within Groups & 658.464 & 671 & .981 & & \\
\hline & & Total & 660.204 & 674 & & & \\
\hline & \multirow[t]{3}{*}{ Risk } & $\begin{array}{l}\text { Between } \\
\text { Groups }\end{array}$ & 4.587 & 3 & 1.529 & \multirow[t]{3}{*}{2.393} & \multirow[t]{3}{*}{.067} \\
\hline & & Within Groups & 428.776 & 671 & .639 & & \\
\hline & & Total & 433.363 & 674 & & & \\
\hline & \multirow[t]{3}{*}{ Opportunity } & $\begin{array}{l}\text { Between } \\
\text { Groups }\end{array}$ & .909 & 3 & .303 & \multirow[t]{3}{*}{.318} & \multirow[t]{3}{*}{.812} \\
\hline & & Within Groups & 639.361 & 671 & .953 & & \\
\hline & & Total & 640.270 & 674 & & & \\
\hline \multirow[t]{7}{*}{ Job Type } & \multirow[t]{3}{*}{ Benefit } & $\begin{array}{l}\text { Between } \\
\text { Groups }\end{array}$ & 7.140 & 6 & 1.190 & \multirow[t]{3}{*}{1.088} & \multirow[t]{3}{*}{.368} \\
\hline & & Within Groups & 732.063 & 669 & 1.094 & & \\
\hline & & Total & 739.203 & 675 & & & \\
\hline & \multirow[t]{3}{*}{ Cost } & $\begin{array}{l}\text { Between } \\
\text { Groups }\end{array}$ & 9.808 & 6 & 1.635 & \multirow[t]{3}{*}{1.679} & \multirow[t]{3}{*}{.123} \\
\hline & & Within Groups & 650.396 & 668 & .974 & & \\
\hline & & Total & 660.204 & 674 & & & \\
\hline & Risk & Between & 4.447 & 6 & .741 & 1.154 & .329 \\
\hline
\end{tabular}


Sumerianz Journal of Business Management and Marketing

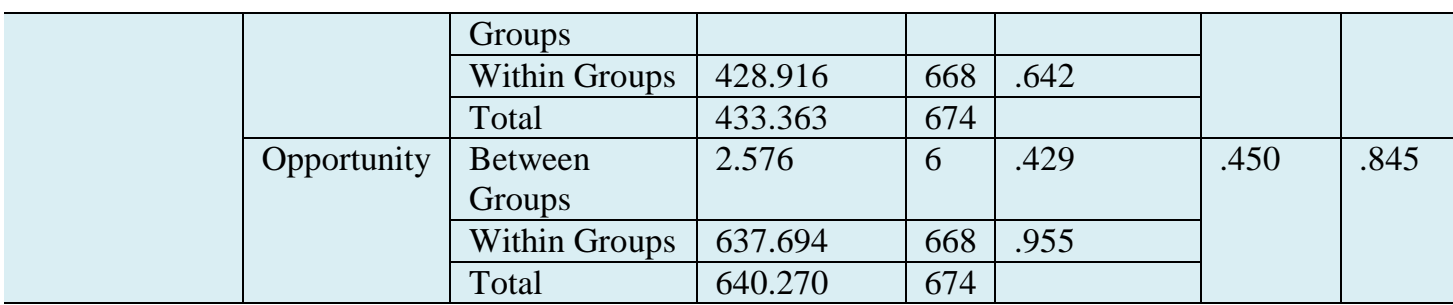

To test hypothesis H3, independent samples T-test and One-Way ANOVA used on this test. Table 6 shows the results of T-test, the gender and education have no statistically significant differences, because the sig values are greater than 0.05 for both tests for gender and education.

Table-6. Testing effect of gender and education on motivate users to use innovative public e-services

\begin{tabular}{|c|c|c|c|c|c|c|c|c|}
\hline $\begin{array}{l}\text { Demographic } \\
\text { information }\end{array}$ & Factor & Type & $\begin{array}{l}\text { Num } \\
\text { ber }\end{array}$ & $\begin{array}{l}\text { Mean } \\
\text { S }\end{array}$ & SD & $\begin{array}{l}\text { T } \\
\text { value }\end{array}$ & df & Sig. \\
\hline \multirow[t]{2}{*}{ Gender } & \multirow{2}{*}{$\begin{array}{l}\text { Motivate users } \\
\text { to use } \\
\text { innovative } \\
\text { public e-services }\end{array}$} & Male & 457 & $\begin{array}{l}3.847 \\
3\end{array}$ & 1.148 & -.554 & \multirow[t]{2}{*}{674} & \multirow[t]{2}{*}{$\begin{array}{l}0.58 \\
0\end{array}$} \\
\hline & & Female & 219 & $\begin{array}{l}3.898 \\
2\end{array}$ & 1.048 & -.572 & & \\
\hline \multirow[t]{2}{*}{ Education } & \multirow{2}{*}{$\begin{array}{l}\text { Motivate users } \\
\text { to } \\
\text { innovative } \\
\text { public e-services }\end{array}$} & $\begin{array}{l}\text { High school } \\
\text { or less }\end{array}$ & 184 & 3.823 & 1.105 & -.567 & \multirow[t]{2}{*}{674} & \multirow[t]{2}{*}{$\begin{array}{l}0.57 \\
1\end{array}$} \\
\hline & & University & 491 & 3.878 & 1.121 & -.570 & & \\
\hline
\end{tabular}

Table 7 shows the results of One-Way ANOVA, the age and job type have no statistically significant differences, because the sig values are greater than 0.05 for both tests for age and job type.

Table-7. Testing effect of age and job type on motivate users to use innovative public e-services

\begin{tabular}{|c|c|c|c|c|c|c|c|}
\hline $\begin{array}{l}\text { Demographic } \\
\text { information }\end{array}$ & Factor & $\begin{array}{l}\text { Sources of } \\
\text { variance }\end{array}$ & $\begin{array}{l}\text { Sum of } \\
\text { squares }\end{array}$ & df. & $\begin{array}{l}\text { Means } \\
\text { squares }\end{array}$ & $\mathbf{F}$ & Sig. \\
\hline \multirow[t]{3}{*}{ Age } & \multirow{3}{*}{$\begin{array}{l}\text { Motivate users to } \\
\text { use innovative } \\
\text { public e-services }\end{array}$} & $\begin{array}{l}\text { Between } \\
\text { Groups }\end{array}$ & .973 & 3 & .324 & \multirow[t]{3}{*}{.259} & \multirow[t]{3}{*}{.855} \\
\hline & & $\begin{array}{l}\text { Within } \\
\text { Groups }\end{array}$ & 839.128 & 671 & 1.251 & & \\
\hline & & Total & 840.101 & 674 & & & \\
\hline \multirow[t]{3}{*}{ Job Type } & \multirow{3}{*}{$\begin{array}{l}\text { Motivate users to } \\
\text { use innovative } \\
\text { public e-services }\end{array}$} & $\begin{array}{l}\text { Between } \\
\text { Groups }\end{array}$ & 12.271 & 6 & 2.045 & \multirow[t]{3}{*}{1.650} & \multirow[t]{3}{*}{.131} \\
\hline & & $\begin{array}{l}\text { Within } \\
\text { Groups }\end{array}$ & 827.830 & 668 & 1.239 & & \\
\hline & & Total & 840.101 & 674 & & & \\
\hline
\end{tabular}

\section{Discussion and Conclusion}

The innovative public e-services aims to provide users with various services electronically to facilitate the use of them as; secure, easy, rapid, and accurate.

To evaluate users' motivation to use innovative public e-services, data was collected from 676 respondents. The results showed that most of the users prefer to complete their transactions by using innovative public e-services. The benefits, cost, and opportunity from using innovative public e-services have good level of acceptance. The users agree that innovative public e-services reduce bribery. The users are satisfied about achieving their services from anywhere and anytime.

The results also showed that gender has no statistically significant differences except with risk and opportunity, because the female gender needs more opportunity and privacy to use the innovative public e-services. For Education, there is no statistically significant difference on all the factors because the factors are not depends on the education levels. Age and job type have no statistically significant differences on all factors, which means that differences in age and job type have no effect on motivate users to use innovative public e-services.

The paper recommended that the innovative public e-services need continuous update specially the security of the services to improve the users confidence toward using innovative public e-services.

\section{References}

Al-Saraireh, J. and Alnabhan, M. (2014). Factors analysis for e-services adoption in jordan: A technology acceptance study. Available: http://dx.doi.org/10.5539/mas.v8n3p192

Alangari, S. (2013). Measuring the service delivery quality. International Journal of Business Review, 5(2): 128-45.

AlBalushi, H. and Ali, S. (2015). Quality dimensions trend analysis in the context of evaluating e-government services. Research Journal of Applied Sciences, Engineering and Technology, 11(3): 315-24. 


\section{Sumerianz, Journal of Business Management and Marketing}

Alomar, M. and Woods, P., 2009. "E-government adoption in the hashemite kingdom of Jordan: Factors from social perspectives." In Proceedings of the International Conference for Internet Technology and Secured Transactions, pp. 1-7, London, 9-12 November, UK.

Alrogibah, A. (2011). The satisfaction level of e-governments services in Saudi Arabia. MSC thesis, De Montfort University, United Kingdom.

Alsultanny, Y. and Alotaibi, M. (2015). Evaluating the factors affecting on intension to use of e-recruitment. American Journal of Information Science and Computer Engineering, 1(5): 324-31.

Alyaqoub, M. (2016). Simulation applied to evaluate and improve the service quality in kuwait's public authority for housing welfare. Unpublished MSc thesis Arabian Gulf University, Kingdom of Bahrain.

Bavarsad, B. and Mennatyan, A. (2013). A study of the effects of technology acceptance factors on users satisfaction of e-government services. World Applied Programming Journal, 3(5): 190-99.

Carter, L. and Belanger, F. (2005). The utilization of e-government services: Citizen trust, innovation and acceptance factors. Information Systems Journal, 15(1): 5-25.

Dhindsa, B., Narang, M. and Choudhary, K. (2013). Benefits and challenges of e-governance portal. International Journal of Soft Computing and Engineering, 5(3): 2231-307.

Field, S. and Kim, S. (2008). A comparison of tests for equality of two or more independent alpha coefficient. Journal of Educational Measurement, 45(2): 179-93.

Gerstman, B. (2003). Statprimer. Available: http://www.sjsu.edu/faculty/gerstman/StatPrimer/

Lehemets, H. (2012). Quality assessment of estonian e-government services. MSC thesis, Faculty of Mathematics and Computer Science, Institute of Computer Science, University of Tartu, Estonia.

Mansoori, E. and Baradaran, K., 2010. "Determining the factors affecting e-customer satisfaction." In Proceedings of the 5th International Conference on Industrial Engineering, July 11-12, Tehran, Iran.

Mazidi, A., Amini, A. and Latifi, M. (2014). The impact of information technology capability on firm performance; a focus on employee customer profit Chain. Iranian Journal of Management Studies, 7(1): 95-120.

Mukumbareza, C. (2014). Evaluating citizen satisfaction with the quality of e-government information services provided by Southern Africa development community governments. MSC thesis, Durban University Of Technology, South Africa.

Orgeron, P. (2011). Evaluating citizen adoption and satisfaction of e-government. International Journal of Electronic Government Research, 7(3): 57-78.

Osman, H., Anouze, A., Irani, Z., Lee, H. and Weerakkody, V., 2011. "A new cobras framework to evaluate egovernment services: A citizen centric." In Proceedings of Gov Workshop'11), March 17 - 18, Brunel University, West London, UK.

Prajakta, W. and Hemalatha, D. (2015). A study of citizen satisfaction for e-governance initiative SETU in Maharashtra (INDIA). International Journal of Computer Applications, 124(17): 12-19.

Ramseook-Munhurrun, P., Naidoo, P. and Nundlall, P. (2010). Service quality in the public service. International Journal of Management and Marketing Research, 3(1): 37-50.

United Nations (2012). E-government development, United Nations. Available: http://www2.unpan.org/egovkb/egovernment_overview/ereadiness.htm

Venkatesh, V. and Davis, D. (2000). A theoretical extension of the technology acceptance model: Four longitudinal field studies. Management Science, 46(2): 186-204.

Waaer, W., 2010. "The role of e-government in improving the quality of government services: A case study of the ministry of interior and local groups." In International Symposium on Quality Management in the Service, 19-21 November, Algeria.

West, D. (2004). E-government and the transformation of service delivery and citizen attitudes. The Journal of Public Administration Review, 64(1): 15-27.

World Bank (2012). E-government work in lac - an emerging strategy. World Bank: Washington, D.C.

Yaghoubi, M., Haghi, A. and Asl, K. (2011). E-government and citizen satisfaction in Iran empirical study on ICT offices. World Applied Sciences Journal, 12(7): 1084-92.

Zikmund, W., Babin, B., Carr, C. and Griffin, M. (2009). Business research methods. 8th edn: South-Western College Publishing: USA. 